\title{
ANGELICA SYLVESTRIS VAR. SYLVESTRIS L.: ESSENTIAL OILS AND ANTIOXIDANT ACTIVITY EVALUATION
}

\author{
Hale Gamze AĞALAR ${ }^{1, *}$, Fatih GÖGER ${ }^{1,2}$, Betül DEMİRCí1, Hulusi MALYER ${ }^{3}$, Neşe KIRIMER ${ }^{1}$ \\ ${ }^{1}$ Pharmacognosy Department, Pharmacy Faculty, Anadolu University, Eskişehir, Turkey \\ ${ }^{2}$ Pharmacy Department, Yunus Emre Vocational School, Anadolu University, Eskişehir, Turkey \\ ${ }^{3}$ Biology Department, Science and Literature Faculty, Uludağ University, Bursa, Turkey
}

\begin{abstract}
In this study, the essential oils and antioxidant activities of A. sylvestris var. sylvestris belongs to the Apiaceae family were evaluated. The essential oils from dried roots, leaves, flowers and fruits obtained by hydrodistillation were analyzed by Gas Chromatography and Gas Chromatography-Mass Spectroscopy, simultaneously. The volatile compounds were characterized by using in-house and commercially libraries. The major compounds were spathulenol (12.4\%), germacrene D (10.6\%), $\alpha$ humulene (7.6\%) in the leave essential oil; elemol (5.4\%), 10-epi- $\gamma$-eudesmol (5.4\%), spathulenol (4.8\%) in the root oil; $\alpha$ pinen $(42.0,23.2 \%)$ and $\beta$-phellandrene $(25.5,9.1 \%)$ in the flower and the fruit essential oils, respectively. The possible antioxidant activities of each essential oil were determined at in vitro conditions. Any essential oil at $10 \mathrm{mg} / \mathrm{ml}$ concentration showed $\mathrm{DPPH}^{\bullet}$ scavenging activity while the fruit essential oil was found to be most active against ABTS ${ }^{\bullet}$ radical. But this effect was lower than gallic acid.
\end{abstract}

Keywords: Angelica sylvestris var. sylvestris, Apiaceae, Essential oil, Antioxidant activity

\section{INTRODUCTION}

Apiaceae family (formerly called Umbelliferae), which has approximately 455 genera and 3751 species and usually spreads in temperate regions, is represented by 102 genus and 451 species in Turkey, according to Flora of Turkey. Later on, 4 genera and 53 species were added to Flora of Turkey [1-7]. Turkey is one of the largest centers of biodiversity for the family among Asian countries [8].

Species belonging to Apiaceae family are generally rich essential oil sources and also contain resin. Essential oil is found in the secretion channels located in all parts of fruit, leaf, root or plant. Some types of Apiaceae are used as both spices and food, and therefore their cultures are also made. Most of the species have economic value and are commercially important $[9,10]$. Members of the Apiaceae family are among economically assessed species in the world and are widely used in food, animal feed, ornamental plants, health and cosmetics industries [11].

This family is very rich in terms of secondary metabolites. Coumarin [12, 13], flavonoid [13-15], acetylenic compounds [13], sesquiterpene lactones [16-18] and essential oils [19-23] are obtained from many genera of the family.

More than 90 species of Angelica L. genus, one of the family members, are known. More than half of these species are used in traditional medicine [24].

Angelica sylvestris L. is known by names of 'wild angelica, European wild angelica', it is similar to A. archangelica $\mathrm{L}$. in terms of their general characteristics. They grow on waterfronts and wetlands. $A$. sylvestris is among medicinal plants used for its roots. It tastes bitter, its scent is light and special. Its

*Corresponding Author: hgduymus@anadolu.edu.tr

Received: 26.03.2019 Published: 31.03.2020 
appetizing, bitter, diaphoretic, carminative and stimulant effects are known. It is also recorded that tea or tincture prepared from its roots are used against respiratory system and nervous system disorders, in cases of fever and colds. The tea is prepared by boiling 2 teaspoons of dry root, which is collected in spring and dried, into 1 cup of water for 5-10 min. and it is drunk as a cup a day. The use of powdered roots in a quarter or half a teaspoon and three times a day is also encountered in the sources. In ethnobotanical studies, uses of $A$. sylvestris have been indicated in cases of indigestion (Italy), disorders of digestive, respiratory and nervous systems, fever, infection and influenza (Austria), antipyretic (Thailand), analgesic, anticarcinogenic effect, arthritis and headache (China) [25-27]. In our country, jam is prepared from stems of this plant grown in the foothills of Bursa, Uludağ, and the plant is known to be fragrant [25].

In studies conducted with Angelica sylvestris, secondary metabolites such as simple coumarins and furanocoumarins (umbelliprenin, bergapten, isoimperatorin, aviprin, byakangelicin, imperatorin, xanthotoxol, bisabolangelone, 5- $\beta$-cyclolavandulyloxy-psoralen, 4-[(2,4,4-trimethyl-1-cyclohexen-1yl)methoxy]-7H-furo[3,2-g][1]-benzopyran-7-one, 1'-O- $\beta$-D-glucopyranosyl-(2S,3R)-3-hydroxymarmesin) [28-31], sterols (sitosterol, stigmasterol, campesterol, cholesterol, stigmast-7-en-3-ol, ergosta-5,24-dien$3 \alpha-o l, \alpha$-saccharostenon [32], essential oils (major compounds as (+)-globulol, limonene, $\alpha$-pinene, farnesol, nonane, $\beta$-phellandrene) $[26,33-36]$ were defined. Studies conducted with essential oils of species and varieties are limited in numbers. In a study conducted in France, it was reported that the yield of essential oil was $0.17 \%$ in fresh roots of A. sylvestris var. elatior Wahlenb., there were nonane (18.7\%), $\alpha$-pinene (16.2\%) and $\beta$-phellandrene (12.0\%) as main compounds. The yields of the dried for one month and fresh root essential oils of A. heterocarpa Lloyd were calculated as $0.03 \%$ and $0.07 \%$, respectively. The main compounds were characterized as nonane (5.2\%), isoheptyl-2-methylbutyrate (3.1\%) and 1-(5-methyl-furanyl)-but-1-en-3-one (2.4\%) [33]. It was determined that fruit essential oil yield of A. sylvestris var. vulgaris Ave-Lallemant was $1.78 \%$, and its main compounds were limonene (56.1\%), $\alpha$-pinene (16.2\%) and $\alpha$-bisabolol (\% 5.8) [34]. From 22 compounds defined in essential oils of A. sylvestris L. seeds growing naturally in Serbia, limonene (66.6\%) and $\alpha$-pinene $(19.0 \%)$ were detected as main compounds [35].

Two varieties of Angelica sylvestris grow in Turkey: Angelica sylvestris var. sylvestris L. and A. sylvestris var. stenoptera Lallem. A. sylvestris var. stenoptera are endemic to Turkey and they grow in Rize. A. sylvestris var. sylvestris, on the other hand, spread in Northern Anatolia, and they grow in provinces of Bolu, İstanbul, Sinop, Trabzon, Bursa, Hatay, Maraş and Karabük in Turkey. Composition of essential oil obtained from hydrodistillation of the fruit of Angelica sylvestris L. var. sylvestris was examined by Özek et al. [26], $\alpha$-pinene (25.6\%), $\beta$-phellandrene $(9.1 \%)$ and limonene $(5.6 \%)$ were determined as main compounds [26].

Nowadays, the essential oils have been gained popularity in industries such as pharmaceuticals, food and cosmetics. Essential oils are complex mixtures that contain different compounds thus, they vary in their biological effects. The researches revealed the effects of various essential oils such as antibacterial, antifungal, antiviral, carminative, choloretic, sedative, diuretic, antispasmodic, analgesic and anticancer effects. In particular, practices of phytotherapy and aromatherapy also increase. This has increased the interest of researchers on essential oils [18, 37-44].

There is literature information available on antibacterial [45- 48], antiiflammatory [46], antioxidant activities [45, 48] and general toxic effects [45] of several extracts of Angelica sylvestris. However, studies on its essential oils seem to be a limited in number [35].

Within the scope of this research, essential oil compounds in roots, leaves, flowers and fruits of Angelica sylvestris var. sylvestris were evaluated separately, and the possible antioxidant effects of each essential oil were examined in vitro. 
Ăgalar et al. / Eskişehir Technical Univ. J. of Sci. and Tech. A-Appl. Sci. and Eng. 21 (1) - 2020

\section{MATERIAL AND METHODS}

\subsection{Chemicals, standards and analytical systems}

Clevenger type apparatus for hydrodistillation (Ildam); UV-spectrophotometer (Shimadzu), microplate reader (BioTek Power Wave XS) and vortex (Heidolph reaxtop) for antioxidant assays; Gas Chromatography system (Agilent 6890 N GC) and Gas Chromatography-Mass Spectrometry (Agilent 5975 GC-MSD) were used for essential oil analyzes. Chemicals and standards: 1,1-diphenyl2-picrylhydrazyl (DPPH') (Aldrich), 2,2'-azino-bis(3-ethylbenzothiazoline-6-sulphonic acid) diammonium salt (ABTS) $\geq 98 \%$ (HPLC) (Sigma), Ethanol absolute (Riedel), Gallic acid (Sigma), Methanol Chromasolv (HPLC grade) (Sigma Aldrich), Sodium persulphate (Sigma), Trolox \% 97 (Aldrich).

\subsection{Plant Material}

The plant was gathered from Bursa: Harmancık Village: from Küplü Hill to Ballısaray, near Ayıcık River and dampy road, Turkey $(692118 \mathrm{D}, 4388556 \mathrm{~N}, 985 \mathrm{~m})$ in 2015. The plant was collected and identified by Prof. Dr. Hulusi Malyer. The herbarium samples were kept at Anadolu University, Pharmacy Faculty Herbarium with ESSE number 14712. The plant materials separated as roots, leaves, flowers and fruits were dried in the shade.

\subsection{Hydrodistillation}

The dry samples were subjected to hydrodistillation for $3 \mathrm{~h}$ by Clevenger type apparatus [49]. The yields of the essential oils were calculated on dry materials. The essential oils were kept at $4{ }^{\circ} \mathrm{C}$ in amber vials.

\subsection{Gas Chromatography (GC) and Gas Chromatography-Mass Spectrometry (GC-MS) Analyzes}

GC-FID and GC-MS analyzes processes were performed with reference to Demirci et al. [49].

\subsection{Antioxidant Activity Evaluation}

\subsubsection{1,1-Diphenyl-2-picrylhydrazyl (DPPH') radical scavenging activity}

The DPPH radical scavenging assay was performed according to Duymuş et al. [50]. Gallic acid was used as positive control. The percentage inhibition was calculated.

\subsubsection{Trolox equivalent antioxidant capacity (TEAC assay)}

This assay assesses the capacity of a compound to scavenge the stable ABTS radical in comparison to the antioxidant activity of Trolox, a water-soluble form of vitamin $\mathrm{E}$ that is used as a standard. The TEAC assay was performed according to Duymuş et al. [50].

\section{RESULTS}

\subsection{The Yields of the Essential Oils}

The yields of the essential oils were calculated as $0.08 \%$ for leaves; $0.52 \%$ for flowers; $1.1 \%$ for fruits and $0.16 \%$ for roots. 
Ăgalar et al. / Eskişehir Technical Univ. J. of Sci. and Tech. A-Appl. Sci. and Eng. 21 (1) - 2020

\subsection{The Essential Oil Analyzes}

The each essential oil was analyzed by GC and GC-MS systems, simultaneously. The volatile compounds were characterized by using in house "Baser Library of Essential Oil Constituents" and commercially libraries "Adams Library, MassFinder Library, Wiley GC/MS Library [51- 53]. The identifications were accomplished by comparison of retention times with authentic samples or by comparison of their relative retention index (RRI) to series of $n$-alkanes $\left(\mathrm{C}_{8}-\mathrm{C}_{21}\right)$. The identified volatile compounds, RRI values and relative percentages were given in Table 1.

Table 1. Angelica sylvestris var. sylvestris essential oil compositions

\begin{tabular}{|c|c|c|c|c|c|}
\hline RRI & Compound & $\mathrm{A}(\%)$ & $\mathrm{B}(\%)$ & $\mathrm{C}(\%)$ & $\mathrm{D}(\%)$ \\
\hline 1032 & $\alpha$-Pinene & - & 23.2 & 42.0 & 1.7 \\
\hline 1035 & $\alpha$-Tujene & - & 0.3 & - & - \\
\hline 1076 & Camphene & - & 2.7 & 4.8 & 0.5 \\
\hline 1118 & $\beta$-Pinene & - & 1.4 & 1.7 & 0.1 \\
\hline 1132 & Sabinene & - & 6.9 & 1.4 & 0.1 \\
\hline 1174 & Myrcene & - & 2.8 & 4.4 & 3.7 \\
\hline 1176 & $\alpha$-Phellandrene & - & 1.0 & 1.0 & - \\
\hline 1183 & Pseudolimonene & - & 0.3 & 0.2 & - \\
\hline 1188 & $\alpha$-Terpinene & - & 0.2 & - & - \\
\hline 1203 & Limonene & 0.4 & 3.4 & 4.2 & 1.3 \\
\hline 1218 & $\beta$-Phellandrene & 0.5 & 34.5 & 25.5 & 0.5 \\
\hline 1244 & 2-Pentylfurane & - & - & - & $\operatorname{tr}$ \\
\hline 1246 & $(Z)-\beta$-Ocimene & $\operatorname{tr}$ & - & - & - \\
\hline 1255 & $\gamma$-Terpinene & - & 0.4 & 0.2 & - \\
\hline 1266 & $(E)$ - $\beta$-Ocimene & $\operatorname{tr}$ & - & - & - \\
\hline 1280 & $p$-Cymene & 0.7 & 1.9 & 1.0 & 0.1 \\
\hline 1286 & 2-Methylbutyl-2-methylbutyrate & - & $\operatorname{tr}$ & 0.1 & 0.2 \\
\hline 1296 & Octanal & - & - & - & 0.6 \\
\hline 1290 & Terpinolene & - & $\operatorname{tr}$ & 0.2 & - \\
\hline 1299 & 2-Methylbutyl-3-methylbutyrate & - & - & 0.1 & 3.0 \\
\hline 1457 & Hexyl isovalerate & - & - & - & 0.3 \\
\hline 1495 & Bicycloelemene & 1.4 & - & - & - \\
\hline 1535 & $\beta$-Bourbonene & 0.6 & - & - & - \\
\hline 1549 & $\beta$-Cubebene & 0.5 & - & - & - \\
\hline 1590 & Bornyl acetate & 0.9 & 2.7 & 4.1 & 2.9 \\
\hline 1600 & $\beta$-Elemene & 1.6 & $\operatorname{tr}$ & 0.2 & 2.1 \\
\hline 1610 & $\beta$-Copaene & 1.2 & - & - & - \\
\hline 1611 & Terpinen-4-ol & - & 0.9 & 0.3 & - \\
\hline 1612 & $\beta$-Caryophyllene & 0.6 & - & - & - \\
\hline 1638 & $\beta$-Cyclocitral & 0.3 & - & - & - \\
\hline 1650 & $\gamma$-Elemene & 0.9 & - & - & 0.5 \\
\hline 1659 & $\gamma$-Gurjunene & 0.4 & - & - & - \\
\hline 1669 & Sesquisabinene & 0.3 & - & - & - \\
\hline 1687 & $\alpha$-Humulene & 7.6 & - & 0.2 & 1.3 \\
\hline 1688 & Selina-4,11-diene & - & - & & $\operatorname{tr}$ \\
\hline 1690 & Cryptone & - & 1.7 & 1.1 & - \\
\hline 1704 & $\gamma$-Muurolene & 0.8 & - & - & 0.3 \\
\hline 1719 & Borneol & 0.4 & - & 0.1 & - \\
\hline 1726 & Germacrene D & 10.6 & - & 0.3 & 1.2 \\
\hline 1740 & $\alpha$-Muurolene & 0.6 & - & - & 1.4 \\
\hline 1744 & $\alpha$-Selinene & 0.4 & - & - & 1.8 \\
\hline 1744 & Phellandral & - & - & 0.2 & - \\
\hline 1755 & Bicyclogermacrene & 3.5 & - & - & 1.1 \\
\hline 1762 & $\alpha$-Chamigrene & 1.0 & - & - & - \\
\hline 1765 & Geranyl acetate & 0.2 & 8.4 & - & - \\
\hline 1773 & $\delta$-Cadinene & 1.0 & - & - & 2.0 \\
\hline 1776 & $\gamma$-Cadinene & - & - & - & 0.8 \\
\hline 1796 & Selina-3,7(11)-diene & - & - & - & 0.1 \\
\hline 1797 & Aromadendra-1(10),4-(15) diene & 0.2 & - & - & - \\
\hline 1802 & Cumin aldehyde & - & 0.2 & - & - \\
\hline
\end{tabular}


Ăgalar et al. / Eskişehir Technical Univ. J. of Sci. and Tech. A-Appl. Sci. and Eng. 21 (1)-2020

\begin{tabular}{|c|c|c|c|c|c|}
\hline 1802 & $(E, E)-2,4-$ Decadienal & 0.3 & - & - & - \\
\hline 1811 & $p$-Mentha-1,3-dien-7-al & - & 0.2 & - & - \\
\hline 1838 & $(E)$ - $\beta$-Damascenone & 0.2 & - & - & - \\
\hline 1853 & Calamenene & 0.6 & - & - & - \\
\hline 1854 & Germacrene B & - & - & 0.3 & 2.6 \\
\hline 1857 & Geraniol & - & 1.1 & - & - \\
\hline 1868 & (E)-Geranyl acetone & 0.9 & - & - & - \\
\hline 1900 & epi-Cubebol & 0.2 & - & - & - \\
\hline 1933 & Neophytadiene isomer & 1.3 & - & - & - \\
\hline 1942 & 4-Hydroxy-2-methyl acetophenone & 3.6 & 2.6 & 3.6 & 1.7 \\
\hline 1957 & Cubebol & 0.4 & - & - & - \\
\hline 1958 & $(E)$ - $\beta$-Ionone & 0.9 & - & - & \\
\hline 2037 & Salvial-4(14)-en-1-one & 0.9 & - & - & \\
\hline 2053 & Germacrene D-1,10-epoxide & 0.2 & - & - & \\
\hline 2071 & Humulene epoxyde II & 2.3 & - & - & 0.6 \\
\hline 2080 & Cubenol & - & - & - & 0.1 \\
\hline 2080 & 1,10-diepi-Cubenol & - & - & - & 0.1 \\
\hline 2081 & Humulene epoxide III & 0.5 & - & - & - \\
\hline 2084 & Octanoic acid & - & - & - & 0.3 \\
\hline 2094 & $p$-Cresol & - & 0.7 & 0.5 & - \\
\hline 2096 & Elemol & - & - & - & 5.4 \\
\hline 2103 & Guaiol & - & - & - & 4.1 \\
\hline 2127 & 10-epi- $\gamma$-Eudesmol & - & - & - & 5.4 \\
\hline 2130 & Salviadienol & 0.7 & - & - & - \\
\hline 2131 & Hexahydrofarnesyl acetone & 0.6 & - & - & - \\
\hline 2144 & Spathulenol & 12.4 & - & 0.2 & 4.8 \\
\hline 2179 & 3,4-Dimethyl-5-pentyliden-2-(5H)-furanone & 0.6 & - & - & - \\
\hline 2209 & T-Muurolol & 0.4 & - & - & 0.3 \\
\hline 2232 & $\alpha$-Bisabolol & & 0.1 & 0.6 & - \\
\hline 2237 & Valerianol & - & - & - & 3.5 \\
\hline 2247 & trans- $\alpha$-Bergamotol & 1.0 & - & - & \\
\hline 2248 & Bulnesol & - & - & - & 4.1 \\
\hline 2250 & $\alpha$-Eudesmol & - & - & - & 3.0 \\
\hline 2255 & $\alpha$-Cadinol & 0.6 & - & - & 3.6 \\
\hline 2257 & $\beta$-Eudesmol & - & - & - & 3.0 \\
\hline 2273 & Selina-11-en- $4 \alpha$-ol & - & - & - & 1.2 \\
\hline 2278 & Torrilenol & 1.0 & - & - & - \\
\hline 2368 & Eudesma-4(15)7-dien-1- $\beta$-ol & 1.7 & - & - & - \\
\hline 2392 & Caryophyllenol II & 1.2 & - & - & - \\
\hline 2500 & Pentacosane & 0.4 & - & - & - \\
\hline 2503 & Dodecanoic acid & 0.3 & - & - & - \\
\hline 2568 & 14-Hydroxy- $\alpha$-muurolene & 0.1 & - & - & - \\
\hline 2607 & 1-Octadecanol & 0.7 & - & - & - \\
\hline 2607 & 14 -Hydroxy- $\delta$-cadinene & 0.3 & - & - & - \\
\hline 2622 & Phytol & 3.6 & - & - & - \\
\hline 2670 & Tetradecanoic acid & 0.4 & - & - & - \\
\hline 2822 & Pentadecanoic acid & 0.2 & - & - & - \\
\hline \multirow[t]{2}{*}{2931} & Hexadecanoic acid & 4.3 & - & 0.2 & - \\
\hline & Total & 79.4 & 97.6 & 98.7 & 66.4 \\
\hline
\end{tabular}

(A), leaves; (B), fruits; (C), flowers; (D), roots; RRI, Relative retention time indices were calculated according to $n$-alkane series; \%, relative percentages were calculated according to FID data; tr: trace amount $(<\% 0.1)$.

Fifty nine volatile compounds were characterised representing $79.4 \%$ of the leave oil. Spathulenol (12.4\%), germacrene D (10.6\%) and $\alpha$-humulene $(7.6 \%)$ were found as major compounds. Sesquiterpenes were the major group in the leave essential oil. Bicycloelemene, $\beta$-elemene, $\beta$-copaene, bicyclogermacrene, $\alpha$-chamigrene, $\delta$-cadinene, neophytadiene isomer, 4 -hydroxy-2-methyl acetophenone, humulene epoxide II, trans- $\alpha$-bergamotol, torrilenol, eudesma-4(15)-7-dien-1- $\beta$-ol, caryophyllenol II, phytol and hexadecanoic acid were other major compounds.

Twenty six compounds were characterized in the fruit essential oil representing by $97.6 \%$ of the oil. Monoterpenes such as $\alpha$-pinene (23.2\%) and $\beta$-phellandrene (34.5\%) were the main group in the oil. In 
A ğalar et al. / Eskişehir Technical Univ. J. of Sci. and Tech. A-Appl. Sci. and Eng. 21 (1)-2020

the same time, the relative percentages of camphene, $\beta$-pinene, sabinene, myrcene, $\alpha$-phellandrene, limonene, $p$-cymene, bornyl acetate, cryptone, geranyl acetate, geraniol ve 4-hydroxy-2-methyl acetophenone were calculated more than $1 \%$ of the oil.

Twenty eight compounds were detected in the flower oil representing by $98.7 \%$ of the oil. $\alpha$-Pinene (42\%) ve $\beta$-phellandrene (25.5\%) were the major. Also, camphene, $\beta$-pinene, sabinene, myrcene, $\alpha$ phellandrene, limonene, $p$-cymene, bornyl acetate, cryptone and 4-hydroxy-2-methyl acetophenone were found as $>1 \%$ of the oil.

Forty three compounds were identified in the root essential oil (66.4\%). Oxygenated sesquiterpenes such as elemol (5.4\%), 10-epi-y-eudesmol (5.4\%) and spathulenol (4.8\%) were the major compounds. The relative percentages more than $1 \%$ compounds were $\alpha$-pinene, myrcene, limonene, 2-methylbutyl-3methylbutyrate, bornyl acetate, $\beta$-elemene, $\alpha$-humulene, germacrene $\mathrm{D}, \alpha$-muurolene, $\alpha$-selinene, bicyclogermacrene, germacrene $\mathrm{B}$, 4-hydroxy-2-methyl acetophenone, guaiol, valerianol, bulnesol, $\alpha$ eudesmol, $\alpha$-cadinol, $\beta$-eudesmol and selina-11-en- $4 \alpha$-ol.

\subsection{Antioxidant activity results}

\subsubsection{DPPH radical scavenging activity}

The $\mathrm{IC}_{50}$ values of tested essential oils except the leaves oil were calculated as more than $10 \mathrm{mg} / \mathrm{ml}$. The leave essential oil had no radical scavenging activity at $2 \mathrm{mg} / \mathrm{ml}$, therefore, the $\mathrm{IC}_{50}$ value was not calculated. The radical scavenging activity was calculated for gallic acid as $\mathrm{IC}_{50}$ value at $0.007 \pm 0.0004$ $\mathrm{mg} / \mathrm{ml}$. According to results, any essential oil showed DPPH radical scavenging activity.

\subsubsection{TEAC assay}

The each essential oil was tested at two different concentrations ( 1 and $10 \mathrm{mg} / \mathrm{ml})$. Any essential oil at $1 \mathrm{mg} / \mathrm{ml}$ was not effective against ABTS radical. At $10 \mathrm{mg} / \mathrm{ml}$ concentration, the most active essential oil was the fruit oil. The TEAC value was calculated as $1.74 \pm 0.3 \mathrm{mM}$ for the fruit essential oil while the TEAC value of the gallic acid was $2.77 \pm 0.05 \mathrm{mM}$ even at $1 \mathrm{mg} / \mathrm{ml}$.

\section{CONCLUSION and DISCUSSION}

As a result of review on Angelica sylvestris var. sylvestris which grows commonly in Turkey, it was determined that there are not many studies available on this subject.

In a study conducted on its fruits, compounds of fruit essential oils obtained by different methods were compared. According to this source, the main compounds of essential oil obtained by hydrodistillation are $\alpha$-pinene (25.6\%) and $\beta$-phellandrene (9.1\%) [26]. In this study, it was determined that essential oil obtained by hydrodistillation of fruits similarly carried $\alpha$-pinene (23.2\%) and $\beta$-phellandrene (34.5\%) as main compounds. This composition also shows similarity to the fruit essential oils of A. archangelica species, which are widely used medically [54]. A. sylvestris var. vulgaris fruit essential oil also includes limonene $(56.1 \%)$ and $\alpha$-pinene $(11.3 \%)$, and it is similar to other subspecies as an essential oil rich in monoterpenes [34].

The amount of essential oil obtained from the roots is $0.16 \%$. Although this amount is close to the amount of essential oil of A. sylvestris var. elatior (the essential oil yield, 0.17\%) in literature [55], it is different from this subspecies containing an oil rich in monoterpene in terms of compound. Root essential oil obtained within the scope of this research was found to be rich in sesquiterpenes. 
Ăgalar et al. / Eskişehir Technical Univ. J. of Sci. and Tech. A-Appl. Sci. and Eng. 21 (1)-2020

Uses of leaves and flower states of A. sylvestris var. sylvestris as a plant material were not found in any studies. Spathulenol, germacrene D and $\alpha$-humulene were identified as main compounds in leaf essential oil. Sesquiterpenes are the major group in leaf essential oil, which is similar to root essential oil. In the flower essential oil, $\alpha$-pinene (42\%) and $\beta$-phellandrene (25.5\%) were identified as major compounds, and the composition of the flower essential oil was found different from leaves and similar to fruit essential oils.

Only one study on antioxidant activity of Angelica sylvestris was found in literature [56]. In that study, the antioxidant activity of methanol extract of $A$. sylvestris sections above soil was examined, and a significant effect was not determined compared with positive controls in experiment systems. As part of our project, it was determined that $A$. sylvestris var. sylvestris essential oils had also low in antioxidant activity, similar to the activity results mentioned in the literature. Although the experimental systems and extraction procedures differ from each other, when the findings were examined, it is the common finding of two studies that $A$. sylvestris was not a potential antioxidant source.

\section{ACKNOWLEDGEMENTS}

This study was financially supported by Anadolu University Scientific Research Projects under grant no 1505 S429.

\section{REFERENCES}

[1] Davis PH. Flora of Turkey and The East Aegean Islands. Edinburgh, England: Edinburgh University Press, 4, 1972. pp. 265-267.

[2] Crowden RK, Harborne JB, Heywood VH. Chemoystematics of the Umbelliferae-A general survey. Phytochem 1969; 8: 1963-1984.

[3] Davis PH, Mill RR, Tan K. Flora of Turkey and the East Aegean Islands. Vol. 10. Edinburgh, England: Edinburgh University Press, 1988. pp. 265-267.

[4] Pimenov MG, Leonov MV. The genera of the Umbelliferae, Whitstable Litho, Whitstable, Kent, Great Britain, 1993.

[5] Güner A, Özhatay N, Ekim T, Başer KHC. Flora of Turkey and The East Aegean Islands. Vol. 11, Edinburgh, England: Edinburgh University Press, 2000. p. 141.

[6] Erik S, Tarıkahya B. Türkiye Florası üzerine. Kebikeç 2004; 17: 139-163.

[7] Özhatay N, Akalın E, Özhatay E, Ünlü S. Rare and endemic taxa of Apiaceae in Turkey and their conservation significance. İstanbul Ecz Fak Mec 2009; 40(1): 1-15.

[8] Şenol SG, Eroğlu V, Pelit NB, Bozyel D. Ekimia ozcan-secmenii (Apiaceae), a new very species from Southwest Anatolia, Turkey. Turk J Bot 2018; 42: 510-517.

[9] Sarker SD, Nahar L. Natural medicine: The genus Angelica. Curr Med Chem 2004; 11(11): 14791500.

[10] Doğan A, Bulut G, Tuzlacı E, Şenkardeş İ. A review of edible plants on the Turkish Apiaceae species. J Fac Pharm Istanbul 2014; 44(2): 251-262.

[11] Güner E. Revision of Seseli L. (Umbelliferae) genus in Turkey. PhD, Gazi University, Ankara, Turkey, 2006. 
Ağalar et al. / Eskişehir Technical Univ. J. of Sci. and Tech. A-Appl. Sci. and Eng. 21 (1) - 2020

[12] Seigler, DS. Coumarins. In: Plant Secondary Metabolism. Luwer Academic Publishers, Springer, Boston, MA, 1998. pp. 130-138.

[13] Wang P, Su Z, Yuan W, Deng G, Li S. Phytochemical constituents and pharmacological activities of Eryngium L. (Apiaceae). Pharmaceut Crop 2012; 3: 99-120.

[14] Zech JC. Flavonoid distribution of Mulinum (Apiaceae, Hydrocotyloideae, Mulineae). Brittonia 1999; 51(4): 415-421.

[15] Shawky E, El Kheir, RM. Rapid discrimination of different Apiaceae species based on HPTLC fingerprints and targeted flavonoids determination using multivariate image analysis. Phytochem Anal 2017; 29: 452-462.

[16] Drew DP, Krichau N, Reichwald K, Simonsen HT. Guaianolides in Apiaceae: perspectives on pharmacology and biosynthesis. Phytochem Rev 2009; 8: 581-599.

[17] Andersen TB, Martinez-Swatson KA, Rasmussen SA, Boughton BA, Jorgensen K, AndersenRanberg J, Nyberg N, Christensen SB, Simonsen HT. Localization and in-vivo characterization of Thapsia garganica CYP76AE2 indicates a role in Thapsigargin biosynthesis. Plant Physiol 2017; 174: 56-72.

[18] Iranshahi M, Rezaee R, Najafi MN, Haghbin A, Kasaian J. Cytotoxic activity of the genus Ferula (Apiaceae) and its bioactive constituents. Avicenna J Phytomed 2018; 8(4): 296-312.

[19] Franz C, Novak J. Sources of Essential oils. In: Handbook of Essential oils: Science, Technology, and Applications (Eds KHC Başer \& G Buchbauer), CRC Press, Boca Raton 2009. pp. 39-81.

[20] Chizzola R. Essential oil composition of wild growing from Europe and the Mediterranean. Nat Prod Commun 2010; 5(9): 1477-1492.

[21] Baser KHC, Kırımer N. Essential oils of Anatolian Apiaceae-A profile. Nat Vol Essent Oil 2014; 1(1): $1-50$.

[22] Sousa RMOF, Rosa JS, Oliveira L, Cunha A, Fernandes-Ferreira M. Activities of Apiaceae essential oils and volatile compounds on hatchability, development, reproduction and nutrition of Pseudaletia unipuncta (Lepidoptera: Noctuidae). Ind Crop Prod 2015; 63: 226-237.

[23] Khoury M, El Beyrouthy M, Eparvier V, Ouaini N, Stien D. Chemical diversity and antimicrobial activity of the essential oils of four Apiaceae species growing wild in Lebanon. J Essent Oil Res 2018; 30(1): 25-31.

[24] Lobiuc A, Zamfirache MM, Stratu A. Physiological aspects in two Angelica L. Taxa (Apiaceae). An Stiint Univ Al I Cuza Iasi Sect II a Biol veget 2012; 58(2): 81-87.

[25] Baytop T. Türkiye'de Bitkilerle Tedavi, Geçmişte ve Bugün, 2. Bask1, İstanbul, Türkiye: Nobel Kitabevi, 1999. pp. 290-291.

[26] Özek T, Özek G, Başer KHC, Duran A, Sagiroglu M. Composition of the essential oils of Angelica sylvestris $\mathrm{L}$. var. sylvestris isolated from the fruits by different isolation techniques. J Essent Oil Res 2008; 20(5): 408-411. 
Ăgalar et al. / Eskişehir Technical Univ. J. of Sci. and Tech. A-Appl. Sci. and Eng. 21 (1)-2020

[27] Vogl S, Picker P, Mihaly-Bison J, Fakhrudin N, Atanasov AG, Heiss EH, Wawrosch C, Reznicek G, Dirsch VM, Saukel J, Kopp B. Ethnopharmacological in vitro studies on Austria's folk medicine- an unexplored lore in vitro anti-inflammatory activities of 71 Austrian traditional herbal drugs. J Ethnopharmacol 2013; 149(3): 750-771.

[28] Muckensturm B, Duplay D, Robert PC, Simonis MT, Kienlen J.-C. Substances antiappétantes pour insectes phytophages présentes dans Angelica silvestris et Heracleum sphondylium. Biochem Syst Ecol 1981; 9: 289-292.

[29] Carbonnier J, Molho D. Furocoumarins in Archangelica officinalis and Angelica silvestris. Distribution of 5-beta-cyclolavandulyloxy-psoralen in the genus Angelica. Planta Medica 1982; 44: 162-165.

[30] Lemmich J, Havelund S, Thastrup O. Dihydrofurocoumarin glucosides from Angelica archangelica and Angelica silvestris. Phytochem 1983; 22(2): 553-555.

[31] Murphy EM, Nahar L, Byres M, Shoeb M, Siakalima M, Rahman MM, Gray AI, Sarker SD. Coumarins from the seeds of Angelica sylvestris (Apiaceae) and their distribution within the genus Angelica. Biochem Syst Ecol 2004; 32: 203-207.

[32] Krzaczek T, Nowak R. Sterols in the roots and fruits from Angelica sylvestris L. Herba Polonica 2000; 46(4): 274-277.

[33] Bernard C, Clair G. Essential oils of three Angelica L. species growing in the France. Part I. Root oils. J Essent Oil Res 1997; 9: 289-294.

[34] Bernard C. Essential oils of three Angelica L. species growing in France. Part II: Fruit oils. J Essent Oil Res 2001; 13: 260-263.

[35] Acimovic M, Varga A, Cvetkovic M, Stankovic J, Cabarkapa I. Chemical characterization and antibacterial activity of the essential oil of wild Angelica seeds. Botanica Serbica 2018; 42(2): 217221.

[36] Vinokurova EY, Shults EE, Bagryanskaya IY, Gatilov YV, Tolstikov GA. (+)-Globulol as a new sesquiterpene alcohol from Angelica sylvestris L. Russ Chem Bulletin 1999; 48: 600-603.

[37] Bansode VJ. A review on pharmacological activities of Cinnamomum cassia Blume. Int J Green Pharm 2012; 6: 102-108.

[38] Fu Z, Wang H, Hu X, Sun Z, Han C. The Pharmacological properties of Salvia essential oils. J Appl Pharmaceut Sci 2013; 3(07): 122-127.

[39] Properzi A, Angelini P, Bertuzzi G, Venanzoni R. Some biological activities of essential oils. Med Aromat Plants 2013; 2(5): doi: 10.4172/2167-0412.1000136.

[40] Ali B, Al-Wabel NA, Shams S, Ahamad A, Khan SA, Anwar F. Essential oils used in aromatherapy: A systemic review. Asian Pac J Trop Biomed 2015; 5(8): 601-611.

[41] Elshafie HS, Camele I. An overview of the biological effects of some Mediterranean essential oils on human health. BioMed Res Int 2017; doi: 10.1155/2017/9268468. 
Ăgalar et al. / Eskişehir Technical Univ. J. of Sci. and Tech. A-Appl. Sci. and Eng. 21 (1)-2020

[42] Ribeiro-Santos R, Andrade M, Sanches-Silva A, de Melo NR. Essential oils for food application: natural substances with established biological activities. Food Bioproces Technol 2018; 11: 43-71.

[43] Damasceno CSB, Higaki NTF, Dias JFG, Miguel MD, Miguel OG. Chemical composition and biological activities of essential oils, in the family Lauraceae: A systematic review of the literature. Plant Med 2019; 85(13): 1054-1072.

[44] Zhong Y, Hu P, Huang X, Yang M, Ren G, Du Q, Luo J, Zhang K, Li J, Wu H, Guo Y, Liu S. Sedative and hypnotic effects of compound Anshen essential oil inhalation for imsonia. BMC Complemt Altern Med 2019; 19: doi:10.1186/s12906-019-2732-0.

[45] Sarker SD, Eynon E, Fok K, Kumarasamy Y, Murphy EM, Nahar L, Shaeen EM, Shaw NM, Siakalima M. Screening the extracts of the seeds of Achillea millefolium, Angelica sylvestris and Phleum pretense for antibacterial, antioxidant activities and general toxicity. Oriental Pharm Experiment Med 2003; 3(3): 157-162.

[46] Kittisrisopit S, Parnthong S, Itharat A. Antiinflammatory and antimicrobial activities of Thai plant extracts for hemorrhoid treatment. Thai J Pharmacol 2010; 32(1): 119-121.

[47] Canlı K, Yetgin A, Akata I, Altuner EM. In vitro antimicrobial activity of Angelica sylvestris roots. Int J Biol Sci 2016; 1(1): 1-7.

[48] Stankovic N, Mihajilov-Krstev T, Zlatkovic B, Stankov-Jovanovic V, Mitic V, Jovic J, Comic L, Kocic B, Bernstein N. Antibacterial and antioxidant activity of traditional medicinal plants from the Balkan Peninsula. Wageningen J Life Sci 2016; 78: 21-28.

[49] Demirci B, Yusufoglu HS, Tabanca N, Temel HE, Bernier UR, Agramonte NM, Alqasoumi SI, AlRehaily AJ, Başer KHC, Demirci F. Rhanterium epapposum Oliv. Essential oil: Chemical composition and antimicrobial, insect-repellent and anticholinesterase activities. Saudi Pharmaceut J 2017; 25: 703-708.

[50] Duymuş HG, Göger F, Başer KHC. In vitro antioxidant properties and anthocyanin compositions of elderberry extracts. Food Chem 2014; 155: 112-119.

[51] Adams RP. Identification of Essential Oil Components by Gas Chromatography/Mass Spectrometry. Carol Stream, IL: Allured Publ. Corp, 2007.

[52] Hochmuth DH. MassFinder-4, Hamburg, Germany: Hochmuth Scientific Consulting, 2008.

[53] McLafferty FW, Stauffer DB. The Wiley/NBS Registry of Mass Spectral Data, New York: J. Wiley and Sons, 1989.

[54] Nivinskienë O, Butkienë R, Mockutë D. Chemical composition of seed (fruit) essential oils of Angelica archangelica L. growing wild in Lithuania. CHEMIJA 2005; 16(3-4): 51-54.

[55] Bernard C, Clair G. Essential oils of Three Angelica L. species growing in France. Part I. Root oils. J Essent Oil Res 1997; 9: 289-294.

[56] Orhan IE, Tosun F, Skalicka-Woźniak K. Cholinesterase and tyrosinase inhibitory, and antioxidant potential of randomly selected Umbelliferous plant species and the chromatographic profile of Heracleum platytaenium Boiss. and Angelica sylvestris L. var. sylvestris. J Serbian Chem Soc 2016; 81(4): 357-368. 